\title{
The Impact of Motivation on Organisational Citizenship Behaviour (OCB): The Mediation Effect of Employees' Engagement
}

\author{
Safaa Shaaban \\ Business Department, Faculty of Business Administration, Economics \& Political Science, The British University in Egypt (BUE), El \\ Shorouk City, Cairo, Egypt \\ Email address: \\ Safaa.shaban@bue.edu.eg \\ To cite this article: \\ Safaa Shaaban. The Impact of Motivation on Organisational Citizenship Behaviour (OCB): The Mediation Effect of Employees' \\ Engagement. Journal of Human Resource Management. Vol. 6, No. 2, 2018, pp. 58-66. doi: 10.11648/j.jhrm.20180602.13
}

Received: June 26, 2018; Accepted: July 17, 2018; Published: August 8, 2018

\begin{abstract}
Employee motivation and citizenship behaviours have become important issues in human resource development (HRD). This study examines the relationship between employee motivation, and Organizational Citizenship Behaviours (OCB). The objectives of this research have two folds: (1) to show to what extent does employees' motivation in the Egyptian governmental sector can affect OCB. (2) To investigate the mediation role of employees' engagement in the employee motivation -citizenship behaviours relationship. This study was applied at Ministry of Civil Aviation (MOCA) where a sample consists of 300 employees working in (MOCA) were chosen based on their participation in the "future leaders program (FLP)" implemented by the ministry as part of Egyptian strategy 2030. The participants of the FLP were chosen by the ministry based on two criteria: having postgraduates' qualification and aged between 30 and 45. A mixed design that combining both qualitative and quantitative methods was applied through questionnaires, in-depth interviews and PLA (Participatory Rapid Approach) using focus groups. A statistical SPSS used to test the hypothesized relationships regression, correlation, Hierarchal multiple regression analysis was used. The study' results revealed that OCB can be developed throughout the application of extrinsic motivation more than intrinsic motivation among employees in the MOCA. The mediation role of employees' engagement was supported. The study recommended that Ministry should increase the engagement task for highly qualified employees in clear structure tasks.
\end{abstract}

Keywords: Employee Engagement, Motivation, Organisational Citizenship Behavior (OCB)

\section{Introduction}

Recently, human resource development (HRD) has been considered as having an important part strategic planning in the organisation context if it is success or failure. Many academics and researchers show an interest in designing models that explain how HRD can affect different aspects and behaviours pertaining to employees [1]. Currently many scholars contributed to developing the concept of engagement in literature and have given a clear understanding of engagement and its effect on organisation' results, with the regard to employee behaviour and performance [2]. Employee engagement is a vital feature which has a major optimistic effect on motivation and OCB, and within the concept of OCB, scholars like [3] mentioned the impact of OCB on employee behaviour and how it reduced employees' intentions to leave [4].

A harmony among scholars and executives which stresses on swapping from reward related pay, as a motivation, to long-term engagement strategy. [5] pointed out that employee engagement is the most effective tool for intrinsic and extrinsic factors of motivation [5]. One of the main purposes of short and long-term strategies is facilitating the engagement within the organisation [6]. Employee motivation was and is still the main concern for any organisation [7]. To reach the desire of level of employee motivation to achieve their goal, organisations should have short and long-term strategies for motivation throughout engagement.

The concept of Employee engagement is evolving in many 
fields such as human resources, employee relations, organizational behaviour, development and organisational [8]

The two main points of debate around engagement are: Firstly, engagement is considered as collection of behaviours that not limited to being engaged but also includes the behaviours which might track back from this state (such as focused performance). Many authors support this argument such as [9 10]. This study supports this point of view since it provides a crucial separation between state engagement (being engaged) and passed behaviours that might follow from this state [11]. Second, the engagement types are not necessarily distinct. It has recently been acknowledged that engagement is under-theorised and there needs to be theoretical development of both engagement and its operationalization [9]. Therefore, employee engagement needs further development if it is to make a strong contribution to the HRD field.

The rationale of the current study is to highlight how important to improve the skills and motivation of employees before engagement in extra task and organisation be able to direct their skills and energy in the direction of task that serve the organisation goal, because training will motivate them to achieve the task that allocated for them and shows Organisational Citizenship behavior. The factors that make motivating government sector employees a challenge for those in managerial positions include having goals that can often be difficult to be divided into small aims that are objectively measurable [12]. This study focusses more on the slot of employees that government prepare them for future leaders and to allocated specific tasks. The criteria government set for future leaders are employees who have a postgraduate qualification and were aged between 30 and 45 . Those employees have two months orientations and training for the allocated task for employees.

Thus, the study contributes to our knowledge of employee motivation and engagement in the governmental organisations for those categories. This study will explore the relationship between motivation and OCB and examine the role of engagement as a mediator in this relationship. The final contribution of this study is to examine how motivation affects employee engagement and OCB in the governmental organisations where these rigid legislations and policies that control this sector.

The concept of motivation, employee engagement and OCB will be reviewed in the next section, starting with how motivation has been developed and defined in the academic literature, and its relationship with other concepts such as engagement and OCB. In the following two sections, we introduce the theoretical framework of this study.

\section{Literature Review}

\subsection{Motivation}

Motivation can be defined as many researchers and authors suggested as the psychological impetus which control the level of effort of the person, as well as the persistence of person ${ }^{e e}$ in obstacles facing in the workplace [13]. It is also defined as "a cognitive decision-making process that influences the persistence and direction of goal directed behaviour" [14]. Another definition "Work motivation can also be defining as the psychological forces within a person that determines the direction of that person's behaviour in an organization" [15].

The main components in the definition mentioned above are; effort, the direct power and different route for behaviour and effort. These mentioned words are translated the approach people use to reach to high level of performance which will benefits their organisations with persistent. As explained by [16] to have the desire to achieve something is called motivation. Thus, if a person is "moved to do something to achieve an end, this is considered a form of motivation, while if someone should do something and s/he is not moved or inspired to do it this is called demotivation or un-motivation [16].

Authors such as [17] emphasise that, there is a high need for more research and study on motivation include wider view for more clarification the concept on the level of behaviour of employee in the work place in the public sector. The Literature reveals that the different between motivation among privet sector employees and their managers rather than employees and their managers' public sector [18].

A clear and deep understand of the context of motivation is consider the two different type of motivation are intrinsic and extrinsic. Based on [19], motivation required basic need are employee engagement in workplace, which divided into two categories are; intrinsic and extrinsic motivation. The two components of motivated people to be engaged in doing the task lead to achieve specific goal has been mentioned by [19]. On the level of intrinsic motivation concept, it refers to the person internal principles to achieve the task and work obligations, whereas extrinsic motivation concept refers to individual want to accomplish specific outcomes such as (money or rewards) that, allied with the same duties and task [19]. Intrinsic concept is related to the pleasure of the person himself.

To conclude, the intrinsic motivation style refers to the need internally, whereas the extrinsic motivation style refers to the external needs that interpreted to the external environments. Both approaches and style of motivation are needed within the organisation, to achieve suitable work environment, and on individual level to achieve employees' satisfaction and engagement [20].

\subsection{Organizational Citizenship Behaviours (OCB)}

Over two decades there is theoretical and empirical examination on the concept of OCB indifferent sector and the OCB experiences and result have been analysed [21]. OCB is defined as "individual behaviour that is discretionary, not directly or explicitly recognized by the formal reward system, and that in the aggregate promotes the effective functioning of the organization" [22]. Recently, OCB was defined according to its connection with performance, as 'performance that supports the social and psychological 
environment in which task performance takes place' [22].

The benefits of OCB are; firstly, engaged employees is more likely their managers scored them with good performance [23]. This is because engaged employees, their boss like them more and perceived more favourably [22]. Secondly, is relating reward and performance, for example bonuses pay increments, promotions or work-related welfares[23]. Thirdly, those individuals scored high performance and obtain larger benefits and rewards, in the situation of economic hardship downsizing, their chance redundant is less than other employees [24].

Seven common dimensions had been created based on examination of the literature by [23]. These dimensions are helping behavior, sportsmanship, organizational loyalty, organizational compliance, individual initiative, civic virtue and self-development [23]. But there are some conceptual overlaps between concepts such as altruism and courtesy of Organ's OCB [23].

\subsection{Employee Engagement}

Different scholars and researchers have defined the context of employee engagement. When talking about the engagement of employee in work place, literature considered William A. Kahn's as a founder who first introduced of the concept [25]. He defined employee engagement as "the harnessing of organization member' selves to their work roles in which people employ and express themselves physically, cognitively, and emotionally during role performance" [25]. Another definition raised by [26] which focuses on engagement is related to psychological attendance, and he define it as "cognitive availability and amount of time one spends thinking about a role", while absorption "means being engrossed in a role and refers to the intensity of one's focus on a role" [26]. Another definition for employee engagement is the willingness and the ability of the employee to contribute to the company's success, through putting extra effort, time and energy into the work [27]. Another author such as [28] mentioned that employee engagement is "an individual employee's cognitive, emotional, and behavioral state directed toward desired organizational outcomes" [26]. Another definition raised by [9] considering engagement as "high level of energy and high levels of engagement in work.

A model has been developed by Khan for engagement including the re-engineering and deployment of the resources of intra-individual to complete and achieve their work role [25]. Khan introduced engagement as a concept through three surfaces (physical, cognitive and emotional) [25]. Based on khan's theory of engagement, people engaged in work based on three concepts which are physical, emotional and cognitive while they perform their take and work.

\subsection{Relationship Between Variables/Mediation Role of Engagement}

Diverse of researches have revealed that once the employees are engaged, consequently they eventually rewarded [23], because of this reward considered as one of the main component of motivation, so employees when engaged in job they expected future reward, that likely to inspires or motivate them to shows OCB. While other studies explained that motivation not the main lead to OCB [2930]. But, the main important argument is that, people behave because of their values and believes [30].

Many researchers such as [31] pointed that, there is a major relationship between motivation and OCB. Finkelstein and colleagues [31] pointed in their study that, the relationship between organisational interest and values motives of people and OCB is a crucial.

Furthermore, [32] suggested that, OCB behaviour is cumulative behavioural activities, person's scoring high level in intrinsic motivation are those who enjoy doing tasks and duties and these people generate enjoyable working atmospheres. Apparently, employees seeking pleasant work environments are more helping in creating the culture of helping in work, which will lead employees to OCB behaviour. Research conducted by [49] used a meta-analysis study to test the impact of extrinsic rewards on intrinsic motivation. Their study result reported that a physical benefits and rewards significantly weakened/ threatens the intrinsic motivation. Authors such as [33] stated that materialistic attitude is negatively affected OCB. While, [34] discovered a small negative relationship between $\mathrm{OCB}$ and instrumental motivation. Based on the results mentioned in research mentioned in early discussion, there is a negative relationship between instrumental motivation and $\mathrm{OCB}$ is predictable.

As a result of the positive relationship between the variables employee engagement and OCB. Then there is a connection between employee engagement and many business results including higher productivity, organizational commitment, and job satisfaction. Nevertheless, employee engagement is working on the individual level and it has an impact on the individual outcomes, the individual level should to reflect on the organisational level [35]. Although neither [25] nor [35] highlighting their researcher results, [25] suggested that engagement leads to both individual level and organisational level outcomes. [3] mentioned that, the employees' engagement concept has been tested as a potential predictor in many OCB studies. Which explain that, employee engagement is related to $\mathrm{OCB}$, individual may behave within the OCB framework under the emotional component [36]. This behaviour has a direct result of employee emotion is consistent with models suggesting by different scholars [37]. Social exchange and emotion are related to each other as, employee prefer to be treated from their organisation will satisfied their needs to reciprocate and positive emotion. Employee engagement is constructive and responsible behaviour at work, which is considered as $\mathrm{OCB}$ [38].

The mediation role of employees' engagement between motivation and OCB has been proved as a significant relation according to [11]. Other researchers such as [39] argue that HR Practices such as engagement is referred to employees' 
results like, job stratification, organizational commitment and OCB, and turnover. [40-11] mentioned that job resources expected to link to engagement and engagement linked to expected results. So, the possibility of mediation role of engagement between the relationship between motivation and $\mathrm{OCB}$ as an outcome of the job it is highly expected, this argue s more consistence with [41] model. Furthermore, numerous studies have identified that engagement mediates the relationship between job variables such as motivation and other job outcomes such as OCB [39-42].

\subsection{The Conceptual Proposed Model}

The variables of this study are as follows: the independent variable is motivation divided into (Intrinsic and extrinsic), the dependent variable is organizational citizenship behaviours (OCB), and the Mediator Variable is Employee engagement.

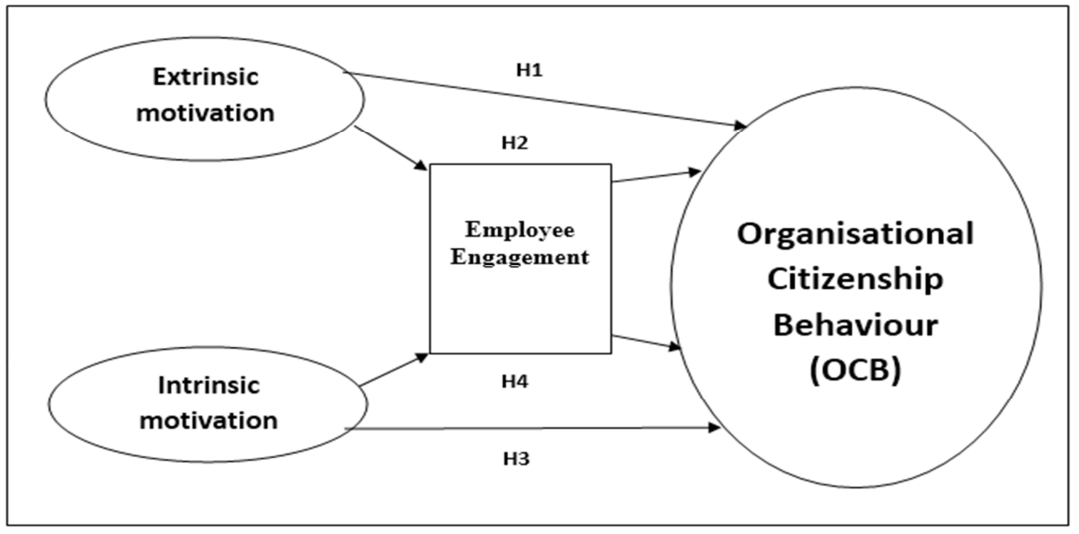

Figure 1. The proposed model.

\section{Research Aims and Hypothesis}

The drive of this study is to test the relationship between motivation and OCB in the government sector in Egypt. Also, the study aims to test employee engagement as mediator variable and the research was implemented in the Ministry of Civil Aviation (MOCA) in Egypt.

This study testing the following hypotheses:

H1: There is a positive relationship between extrinsic motivation and OCB

$\mathrm{H} 2$ : Employee Engagement mediate the relationship between extrinsic motivation and organisational OCB

H3: There is a positive relationship between intrinsic motivation and individual engagement.

H4: Employee Engagement mediate the relationship between intrinsic Motivation and individual OCB.

\section{Methodology}

\subsection{Preliminary Step}

In the pre-tested stage content validity that was done by expert opinions of two university research specialists in quantitative methodology professors. As suggested by [42], the pre-tested scale was tested on 25 employee respondents who they have the similar characteristics to the sample target group. The PLA focuses group discussion target two main points are, (1) to explain the main purpose of research and how motivation of employee can affect their OCB behaviour, also the if the employees engaged in tasks would this increase their OCB behaviour. (2) To reveal the significant of this study objectives from two prospective academics and practitioners.

\subsection{Research Design}

The Mixed Methods Studies term is raises based on the perspective of combined or mixing two research strategies of quantitative and qualitative data to produce away from testing and investigate a phenomenon or clarifying certain situation. The main idea behind this methodology is rather than you build your result separate quantitative and qualitative data collection and analysis, you become dependent on a more complete and utilization of data for one mixed approach [43]. The evaluation of personality and engagement provide a clear opportunity for mixed methods studies to contribute to training, learning and capacity building program should apply for an employee in these two ministries, and how to improve the leadership skills and best task each person should fit. Also, it helps the researcher to identify which personality traits will be dominant a leading the engagement dimensions.

This research is investigating relationship of employee motivation, engagement and OCB in the government organisation in Egypt, in the MOCA. This relationship has never been addressed before in the government sector and most of the literature focuses on private sector business rather than the public sector. The data gathered was primary data in the questionnaire form, confirmed by interviews with the target group.

\subsection{Measurement Instruments}

The questionnaire consists of a set of questions which are given to a group of employees selected based on (employees who have postgraduate qualifications), aged from 30 to 45 . The questionnaire was classified into four divisions. The first 
division, is demographical information about the employee such as; age, gender and qualifications. The second section measures motivation (intrinsic and extrinsic) using ten statements developed from [44] motivating factors scale. The third section is employee engagement which taken from [45]. And finally, the forth section is OCB which includes fourteen statements taken from Fields, D. (2013), these statements divided into 2 section OCB individual level and for OCB organisation level. The questions are closed ended questions in all the sections, using likert scale for rating from (1-5) show how strongly the employees agree or disagree on specific question.

\subsection{Qualitative Approach PLA (Participatory Learning \& Action) Focuses Group Interview Workshop}

The second approach and methodology chosen in this study is PLA. The PLA is an approach of different approaches of action research. According to Robert Chambers, a PLA research route creates various stakeholders to engage in a shared process to enriched learning-based participant participation. A PLA 'mode of engagement' helps in cooperation, reciprocity, dialogue and mutual respect in research. This promotes in encounters within and across responds and stakeholder participated in the research study [46]. According to different studies has been conducted PLA techniques are user-friendly and democratic, inclusive, verbal and tangible data, generating and combining visual, and to confirm the finding of any research [47 - 48]. The approach as a qualitative research using a collection of tools such as charting, mapping, ranking and assessment practices are with focus groups interviews. The concept of including the sample as a stakeholder groups engage in PLA dialogue to recognize, in a democratic way the result of their responds the questionnaires or survey and add on the practical level the missing part still not add to the theory [48]. PLA researchers' performance as facilitators than directors or decision-makers which allow trusted strong relationships [49]. PLA tactic and style are to prompt for an active research process designed to encourage and support the responders' significant engagement.
A workshop held after the statistical analysis of the transformational/ transaction and resilience survey. The purposes of this workshop 2 parts, first explain the meaning and applications of transformational style of leadership and transactional style of leadership, also this to present the statistical results to the responders and to see if they are agreed about this result of this study translated the real situation in their sector.

\subsection{Sampling System and Criteria}

The research study was conducted in the beginning of 2016 using a questionnaire submitted for the selected sample by hand to 300 employees working in the Ministry of Civil Aviation. The sample was chosen carefully based on specific criteria. These criteria were: employees aged from 30 to 45 and holding a postgraduate certificate (Diploma, Master and $\mathrm{PhD}$ ), these criteria are the ministry future leaders programme criteria, the future leaders programme is the government strategy target young generation in Egyptian government sector and public sector companies, which is depend on selecting a specific group in each ministry based on the criteria mentioned above in Egypt to be trained, empowered and reinforced to be a target pool for future top management and leaders selection in the ministry. Total population of these group of employees are around 1000 employees in each ministry, this population has completed the MBAs program from academic institute's to be ready to be engaging to different tasks in their government organisations and companies as a leader.

Table 1. Sample characteristics.

\begin{tabular}{ll}
\hline Characteristic & Description \\
\hline Age & $\mathrm{M}=38.46$ years $-\mathrm{SD}=3.62$ \\
\hline Gender & \\
Male & $48 \%$ \\
Female & $52 \%$ \\
\hline
\end{tabular}

These characteristics show a rational mix of demographic sample groups represented targeted in data collection.

\section{Research Results}

Table 2. Descriptive statistical, correlation coefficients and reliability of study variables.

\begin{tabular}{|c|c|c|c|c|c|c|c|}
\hline \multicolumn{8}{|l|}{ Correlations } \\
\hline & Mean & Std. Deviation & Motivation & Intrinsic & extrinsic & engagement & OCB \\
\hline Motivation & 31.2200 & 4.55934 & 1 & $.487^{* *}$ & $.601^{* *}$ & $.554^{* *}$ & $.609^{* *}$ \\
\hline Intrinsic & 16.4333 & 3.14938 & $.487^{* *}$ & 1 & $.797^{* *}$ & $.802^{* *}$ & $.337^{* *}$ \\
\hline extrinsic & 18.8433 & 3.73255 & $.601^{* *}$ & $.797^{* *}$ & 1 & $.839^{* *}$ & $.487^{* *}$ \\
\hline engagement & 34.1800 & 8.84241 & $.554^{* *}$ & $.802^{* *}$ & $.839^{* *}$ & 1 & $.567^{* *}$ \\
\hline $\mathrm{OCB}$ & 42.1133 & 5.86531 & $.609^{* *}$ & $.337^{* *}$ & $.487^{* *}$ & $.567^{* *}$ & 1 \\
\hline
\end{tabular}

**. Correlation is significant at the 0.01 level (2-tailed).

Built on theoretical and empirical valuations there is a positive relationship between motivation, employee engagement, and OCB. The statistical result showed in table 2 inter correlations between all variables, Means, standard deviation, and scale reliabilities.

The Correlation is positive and significant between OCB and employee engagement $(r=0.820, p>0.01)$. As shown in Table 2, hypothesis 2 was supported, Testing the third hypothesis, the statistics support the hypothesis that the relationship between employee engagement and OCB is correlated and positive,

As shown in Table 2 correlation between employee 
engagement and motivation was positive and significant $(\mathrm{r}=$ $0.818, \mathrm{p}>0.01)$. As shown in Table 2, hypothesis 2 was supported. Correlations between motivation and OCB were positive as well and significant $(\mathrm{r}=-0.826, \mathrm{p}>0.01)$. As shown in Table 2, hypothesis 1 is supported.

To test Hypotheses (2) and (4) a hierarchical multiple regression was used in two steps are, first the motivation (extrinsic and intrinsic) as independent variable to predicate OCB. Second is the engagement entered in the regression equation as a second predicator (independent variable). The result presented in table 3 and table 4.

Table 3. Hierarchal multiple regression analysis.

\begin{tabular}{|c|c|c|c|c|c|}
\hline Model & b & t-value & R-Square & $\bar{F}$ & Sig. \\
\hline $\begin{array}{l}\text { First step } \\
\text { Extrinsic Motivation }\end{array}$ & .765 & 9.620 & .234 & 38.132 & $.000^{\mathrm{b}}$ \\
\hline Second step Extrinsic Motivation engagement & $\begin{array}{l}.060 \\
.355\end{array}$ & $\begin{array}{l}.431 \\
6.084 \\
\end{array}$ & .317 & 83.542 & $.000^{\mathrm{c}}$ \\
\hline
\end{tabular}

** Coefficient is significant at.01 level

Table 4. Hierarchal multiple regression analysis.

\begin{tabular}{|c|c|c|c|c|c|}
\hline Model & b & t-value & R-Square & $\mathbf{F}$ & Sig. \\
\hline First step Intrinsic Motivation & 627 & 6.175 & .237 & 70.364 & .000 \\
\hline Second step Intrinsic Motivation engagement & $\begin{array}{l}.616 \\
.552 \\
\end{array}$ & $\begin{array}{l}4.252 \\
10.698\end{array}$ & .321 & 92.535 & .000 \\
\hline
\end{tabular}

** Coefficient is significant at.01 level

\section{Discussion}

In response to the objectives of this study reflected in the title "The impact of Motivation on Organisational citizenship behaviour (OCB): The mediation effect of employees' engagement" the answer is, the relationships between study variables are positive, the relationship between employee engagement and OCB is a positive as well between engagement and OCB is a positive. When first looking at the analysis of primary category data, this shows that there is a positive relationship between all the variables.

The problems related to the workforce that the public sector generally faces, are demotivation, lack of commitment, lack of the feeling of responsibility and lack of OCB behaviour. The causes of these problems are: Firstly, the leadership, centralizing attitudes, a result of mangers orientation of their employees' due to fear of losing their position, prevent positive attitudes of employees. Moreover, the existence of reward or promotion or even the completed of activities is based, on closeness or friendship between manager and employee. Secondly, regarding the organisational structure, policy and procedure, as the process should work strictly according to the law, and in any procedures, you should follow the rules. As well as, the specific characteristics of the government public such as structure, bureaucracy, political environment will not take into consideration to improvement initiatives, these initiatives could not successes as expected because of these characteristics. Thirdly, and finally, the lack of sufficient training related to job, in addition to formal control created difficulty of system improvements and corroborate from employee lead to process inefficiency.

The main finding of this study is that engagement is fundamentally engaged with motivation. OCB is considered as an extra behaving role because engagement attached employees with their work duties. Normally in government sector employees struggle to meet the expected task related to their job, in engagement to ask them for an extra task somehow related to their job department, other colleagues or whole organisation. However, this study has proven that, the motivation with engagement is cause an OCB while engagement is considered as mediating the relationship with the condition of preparing the employee for specific task and let employees' aware of what expected from them.

Many scholars have confirmed that the relationship is positive between motivation and OCB. Researchers such as [3-36] confirmed that relationship between employee motivation and OCB. The statistics in Table 2 shows that there is a correlation between motivation and its two approaches and OCB. In the government sector employee engagement will lead to OCB because employees will find meaning at work and in what they are doing.

Other scholars such as Finkelstein \& Penner; Rioux \& Penner stated in their study statistically that, there is an important relationship between motives and OCB. Nevertheless, this study reports a strong correlation may have been subjected to shared process and source that affect the relationship between the two variables. While different researchers in their study pointed that, there is a vital relationship between causes of motivation and the behaviours of leaders' that can lead to OCB [34]. Then the variables relationship based on different reasons such as leadership, personal goals, managers and colleagues' relationships and 
other reasons. Employees in the government sector sometimes behave according to the concept of motivation but because what motivate them? An essay explanation that employees are motivate are likely to engage and to achieve extra role and behavior as organisational citizenship because of they are motivated to complete their role goal and to perform their takes efficiently, which this study confirmed. However, the factor analysis shows that there is a strong relationship between intrinsic motivation, engagement and OCB. The explanation of this more focused strong relationship factor analysis proved is Government sector employees are motivated to engage on the task that is related to helping of other employees like their colleagues, manager or leaders based on they liking with them with belonging relationship, such as closer friend, relatives, and leader they like, so they achieved their colleague's task because their intention keep remain these relationship which translated the intrinsic motivation approach, this lead to the OCB on the individual level, so employee doing these extra tasks for their colleagues rather than their government originations.

Employees' engagement is referring to employee not fulfil their official duties but performing extra duties beyond their duties. In engagement employee work with self-obligation and commitment toward their organisation. Engagement works beyond performing extra duties, it is the feeling of enjoying, believing and feeling valued of what they are doing.

\section{Implication Practices}

This study results have several important practical implications. This study shows that there is a positive relationship between motivation and employee engagement. According to Salanova \& Schaufeli, employee engagement comprises the fundamental scope of intrinsic motivation, which confirms goal that direct the behaviour. Engagement level has increases practical work behaviours within the framework of personal initiative, for example, proactive behaviour [50]. Which covered the one of two fundamental approaches in motivation, which is intrinsic motivation throughout the engagement of employees. From positive view, when linking engagement to $\mathrm{OCB}$, it is expected that, employees not focus only to satisfy their official responsibilities, but to pay more effort to do other jobs outside their formal role duties with more passion, committed and loyalty to the organisation. It is the concept of employees feeling esteemed, believing and liking in what they are doing [23].

Some raising recommendations come from this study as following are: (1) to enhance employee engagement, managers' especially top managers should ensure that employees have a clear task which thy engaged lead to the organisational goal. Engagement should to link to reward \& recognition, perceived social support, compensation fairness, job development and job security. In addition, on policy level, the minister as public sector requires to pay careful considered while choosing of top managers and leaders based on set of criteria's rather than seniority while recruiting top managers. [51] pointed that "Managers might be able to increase engagement by designing jobs that include motivating characteristics," (2) this study finds should to consider in develop strategy, plan and interventions to prompt the level of employees' engagement and OCB. (3) Managers need to considered social exchange theory in linking OCB with compensation fairness, role clarity, job security, training and development as major predicator of OCB. A clear explanation for employee engagement is found in exchange theory according to [39]. Also Ariani in 2013 mentioned that exchange theory gives a clear justification and explanation of why employee become more or less engage in their workplace and with tasks led to achieve their organisational goals, engagement considered as to what extend employee is attenuate and absorbed in their performance [51]. (4) Manager should be implementing the engagement in different level of organisational structure, also on the level of group to create the link and cohesion between group members, this will enhance and reinforce the team work. This team will be commitment to achieve their task collectively and the reward should go to the whole team as well.

\section{Conclusion and Future Research}

The concept of employee motivation is considered as an encouraging employee attitude towards the organisation and its vision. Impeding motivation among employees facilitated with engagement can create, develop and increase OCB. This research study provides one answer in that employees who showed higher levels of motivation were found engaged and to translate to OCB. The study also shows that the government sector employees inclined toward the levels of individual OCB when they are engaged in related tasks. Motivation and $\mathrm{OCB}$ are related to each other. If the employee is motivated, engaged the percentage is possible showing high OCB level. The study shows that engagement is mediating the employee motivation and OCB relationship. This study respondent came from a specific group in the Ministry of Civil Aviation, those who are have a high level of qualification. The next study will examine the impact of training and development on motivation with training courses to prepare the employees to be engaged in effective way by engagement on specific task by applying the concept of managing by objectives (MBO).

The Limitations arises from this study, although this study as a cross-sectional research which opposite of longitudinal experimental research, the last one provides absolute conclusion different from a self-reported questionnaire. However, the researcher applies another research approach such PLA explained previously to confirm the findings of this study with sample of the responders. The study findings only applied for the employees in the civil aviation sector in Egypt only. 


\section{References}

[1] Swanson WJ, Aagaard JE, Vacquier VD, Monné M, Sadat Al Hosseini H, Jovine L (2011) The molecular basis of sex: linking yeast to human. Mol Biol Evol 28(7):1963-6

[2] Bakker, A. B., \& Xanthopoulou, D. (2009). The crossover of daily work engagement: Test of an actor-partner interdependence model. Journal of Applied Psychology, 94, $1562-1571$.

[3] Rich, B. L., J. A. LePine, and E. R. Crawford. (2010) Job engagement. Antecedents and effects on job performance. Academy of Management Journal 53: 617-35.

[4] Hallberg, U., \& Schaufeli, W. B. (2006). - Same samell but different: Can work engagement be discriminated from job involvement and organizational commitment? European Journal of Psychology, 11, 119-127.

[5] Silvera, I. (2013). Motivation schemes can build long-term engagement. Employee benefits.

[6] Maccey, W., \& Schneider, B. (2008). The Meaning of Employee Engagement. Industrial and Organizational Psychology.

[7] Amabile, T., Regina, C., Coone, H., Lazenby, J., \& Herrn, M. (1996). Assessing the Work Environment for Creativity. Academy of Managment.

[8] Mcbain, R. (2006). Employee engagement-The emergence of a new construct? Henley Manager, 21-32.

[9] Bakker, A. B., Albrecht, S., \& Leiter, M. P. (2011). Key questions regarding work engagement. European Journal of Work and Organizational Psychology, 20, 4-28.

[10] Parker, S. K., and M. A. Griffin. 2011. Understanding active psychological states: Embedding engagement in a wider nomological net and closer attention to performance. European Journal of Work and Organizational Psychology 20: $60-7$.

[11] Saks, A. M. (2006). Antecedents and Consequences of Employee Engagement. Journal of Managerial Psychology, 21(7), 600-619.

http://dx.doi.org/10.1108/02683940610690169

[12] Jin, M. H. and McDonald, B. (2016) Understanding Employee engagement in the public sector: the Role of Immediate Supervisor, Perceived Organizational support, and Learning opportunities. American Review of Public Administration, 1-23.

[13] (SHRM) Society for Human Resource Management (2010) Employee Benefits: Examining Employee Benefits in the Midst of a Recovering Economy survey report. Colonial Life. USA.

[14] Bratton, J. and Gold, J. (2007). Human Resource Management Theory and Practice. Basingstoke: Macmillan.

[15] George, J. M. \& Jones, G. R. (2012) ${ }_{\text {th }}$ Understanding and Managing Organizational Behaviour. 6 edition. Reading, MA: Prentice Hall.

[16] Ryan, R., and Deci, E., (2000). Intrinsic and Extrinsic motivations: classic definition and new directions. Contemporary educational psychology.

[17] Perry, J. L. (2000). Bringing society in: Toward a theory of public-service motivation. Journal of Public Administration Research and Theory, 10, 471-488

[18] Wright, T. A. and Cropanzano, R. (2000), "Psychological well-being and job satisfaction as predictors of job performance", Journal of Occupational Health Psychology, Vol. 5 No. 1, pp. 84-96.

[19] Kamal, S., Khan, B., Khan, M. B., \& Khan, A. B. (2006). Motivation and its impact on the performance of employee"s. Journal of reserch.

[20] Kim, Sangmook (2006) Pubic Service Motivation and Organizational Citizenship Behavior in Korea, International Journal of Manpower, vol.27 No.8, 2006 pp722-740.

[21] Organ, D. W. (1990). The motivational basis of organizational citizenship behavior. Research in Organizational Behavior, 12, 43-72.

[22] Podsakoff, N. P., Whiting, S. E., Podsakoff, P. M., \& Blume, B. D. (2009). Individual and Organizational Level Consequences of Organizational Citizenship Behavior: A Meta- Analysis. Journal of Applied Psychology, 94(1), 122141. http://dx.doi.org/10.1037/a0013079

[23] Organ, D. W., Podsakoff, P. M., \& MacKenzie, S. B. (2006). Organizational citizenship behavior: Its nature, antecedents, and consequences. USA: Sage Publications.

[24] Khan, w. A. (1990). Psychological conditions of personal engagement and disengagement at work. Academy of Management Journal.

[25] Rothberg, G., (2005, Fourth Quarter). The Role of Idea in the Managers Workplace: Theory and Practice. Pakistan Management. Review, XLII (4), 48-73.

[26] Perrin, T. (2003). Working Today: UnderstandingWhat Drives Emploee Engagement. US: US reports.

[27] Shuck, B., Reio, T. G., \& Rocco, T. S. (2011). Employee engagement: an examination of antecedent and outcome variables. Human resource Development International.

[28] Ryan, R. M., \& Deci, E. L. (2001). To be happy or to be selffulfilled: A review of research on hedonic and eudaimonia well-being. In S. Fiske (Ed.), Annual Review of Psychology (Vol. 52; 141-166). Palo Alto, CA: Annual Reviews/ Inc.

[29] Shamir, B., Zakay, E., Breinin, E., \& Popper, M. (2000). Leadership and social identification in military units. Journal of Applied Social Psychol- ogy, 30, 612-640.

[30] Rioux, S. M., \& dan Penner, L. A. (2004). The Causes of Organizational Citizenship Behavior: A Motivational Analysis. Journal of Applied Psychology, 86(6), 1306-1314. [Online] Available: http://web.ebscohost.com/ehost/detail?vid=8\&hid=118\&sid=e f9a2084-f9e7-4c92-8f00e6df62d67161\%40sessionmgr $13 \&$ bdata $=$ JnNpdGU9ZW hvc3QtbG12ZQ\%3d\%3d\#db=buh\&AN=12129188

[31] LePine, J. A., Erez, A., \& Johnson, D. (2002). The nature and dimensionality of organizational citizenship behavior: A critical review and a meta-analysis. Journal of Applied Psychology, 87(1), 52-65.

[32] Torlak, O., \& Koc, U. (2007). Materialistic attitude as an antecedent of organizational citizenship behavior. Management Research News, 30(8), 581-596. 
[33] Barbuto, J. E., Fritz, S. M., \& Plummer, B. A. (2003). Sex differences among five sources of motivation in the motivation sources inventory: Preliminary findings. Psychological Reports, 93(1), 47-48

[34] May, D. R., Gilson, R. L., \& Harter, L. M. (2004) The psychological conditions of meaningfulness, safety and availability and the engagement of the human spirited work. Journal of Occupational \& OrganizationalPsychology, 77: 1137

[35] Bennett, R. J., \& Robinson, S. L. (2000). Development of Measure of Workplace Deviance. Journal of Applied Psychology, 85, 349-360. http://dx.doi.org/10.1037/00219010.85.3.349

[36] Miles, D. E., Spector, P. E., Borman, W. E., \& Fox, S. (2002). Building an Integrative Model of Extra Role Work Behavior: A Comparison of Counterproductive Work Behavior with Organizational Citizenship Behavior. International Journal of Selection and Assessment, 10(1/2), 51-57. http://dx.doi.org/10.1111/1468-2389.00193

[37] Rhoades, L., \& dan Eisenberger, R. (2002). Perceived Organizational Support: A Review of the Literature. Journal of Applied Psychology, 87(4), 698-714. http://dx.doi.org/10.1037/0021-9010.87.4.698

[38] Schaufeli, Wilmar B., and Arnold B. Bakker. (2004). Job demands, job resources, and their OCB. Journal of Organizational Behavior.

[39] Alarcon, G. M., Bowling, N. A., \& Khazon, S. (2013). Great expectations: A meta-analytic examination of optimism and hope. Great expectations: A meta-analytic examination of optimism and

[40] Podsakoff, N. P., Whiting, S. E., Podsakoff, P. M., \& Blume, B. D. (2009). Individual and Organizational Level Consequences of Organizational Citizenship Behavior: A Meta- Analysis. Journal of Applied Psychology, 94(1), 122141. http://dx.doi.org/10.1037/a0013079

[41] Sonnentag, S. (2003). Recovery, Work Engagement, and Proactive Behavior: A New Look at the Interface between Nonwork and Work. Journal of Applied Psychology, 88(3), 518-528. doi: 10.1037/0021-9010.88.3.518.

[42] Sekaran, U., \& Bougie, R. (2010). Research methods for business: A skill building approach (5th ed.). West Sussex, UK: John Wiley \& Sons Ltd.

[43] Creswell, J. W., \& Plano Clark, V. L. (2011). Designing and Conducting Mixed Methods Research (2nd ed.). London: Sage Publications Ltd.

[44] Tremblay, M. A., Blanchard, C. M., Taylor, S., Pelletier, L. G., \& Villeneuve, M. (2009). Work extrinsic and intrinsic motivation scale: Its value for organizational psychology research. Canadian, Journal of Behavioural Science, 41, 213226. doi:10.1037/a0015167

[45] Soane, Emma, Catherine Truss, Kerstin Alfes, Amanda Shantz, Chris Rees, \& Mark, Gatenby (2012). "Development and application of a new measure of employee engagement: the ISA Engagement Scale." Human Resource Development International, 15 (5), pp. 529-547.

[46] de Brún T, O’Reilly-de Brún M, van Weel-Baumgarten E, van Weel C, Dowrick C, Lionis C, (2015) Guidelines and training initiatives that support communication in cross-cultural primary care settings: appraising their implementability using Normalization Process Theory. Fam Pract. 2015, doi: 10.1093/fampra/cmv022

[47] O'Reilly-de Brún M, de Brún T. (2010) The use of Participatory Learning \& Action (PLA) research in intercultural health: some examples and some questions. Translocations: Migration Soc Change. 6(1).

[48] Chambers, R (2007) 'From PRA to PLA and Pluralism: Practice and Theory' IDS Working $P$ aper 40: Brighton

[49] Sussman AL, Rivera M. (2008) 'Be Gentle and Be Sincere about It': A Story about Community-Based Primary Care Research. Albuquerque: Department of Family and Community Medicine, University of New Mexico.

[50] Salanova, M., \& Schaufeli, W. B. (2008). A Cross-National Study of Work Engagement as a Mediator between Job Resource and Proactive Behavior. The International Journal of Human Resource Management, 19(1), 116-131. http://dx.doi.org/10.1080/09585190701763982

[51] Ariani, D. W. (2012) The Relationship between Employee Engagement, Organizational Citizenship Behavior, and Counterproductive Work Behavior. International Journal of Business Administration, Vol. 4, No. 2. 